\title{
Reading in Secondary Schools
}

\author{
GEORGE E. CARROTHERS

\begin{abstract}
Director, Bureau of Co-operation with Educational Institutions University of Michigan
\end{abstract}

The October, 1942 number of The Nation's Schools contains an article written by F. Dean McClusky in which he laments the fact that oral reading in schools has greatly deteriorated during the past few years. He ascribes the difficulty to the testing programs which have been carried on extensively and to the resultant speeding up of youngsters to a more rapid pace in silent reading. His conclusion is that "over-emphasis on silent reading has made oral reading almost a lost art."

With the statement that oral reading in many schools is almost a "lost art" this writer agrees. Headmaster McClusky has hit on one of the basic explanations of the extremely poor quality of reading in school today, but he has not put his finger on the really fundamental difficulty. There are many factors working together to make oral and silent reading "almost a lost art." Some of the other factors are, (1) The effect on reading of permitting pupils to get the notion that "reading" means merely calling words, (2) The effect on pupils of expecting them to read at sight difficult materials unfamiliar to them, (3) The results of requiring pupils to read selections one to three or four years beyond their ability to comprehend, (4) The effect of asking pupils to read without taking time to teach them how to read, (5) The influence on skill in oral reading of giving pupils opportunity to read only from a book with copies before all other members of the class, (6) The limited extent of comprehension when pupils are called on to read around the class with frequent interruptions, and (7) The results of providing so little time for each pupil to read.

THE MEANING OF THE WORD "READING"

A clarification of the meaning of a word often greatly assists in its correct usage. Webster's dictionary says "reading" means going over the words or characters understandingly. Times without number in secondary schools a pupil is called on to "read" a certain passage; then after the words have been uttered more or less distinctly, the teacher calls on another pupil to read the next paragraph, thus indicating the teacher's belief that the pupil has been reading. On many of these occasions it is clear to the listener that the pupil has no notion of what he has "read." He is merely repeating words.

That sort of exercise is not reading, and it should not be permitted to pass as such. Pupils are being given a false notion, and the sooner we come to understand the meaning of "read" the sooner pupils can be started on the right road toward learning to read. 


\section{READING ALOUD UNFAMILIAR MATERIALS}

The effect on immature pupils of asking them to read orally on first sight materials with which they have had no opportunity to become acquainted is surely and positively harmful in a large number of instances. If the reading matter selected is of such an easy nature that pupils can read it to others on sight, it does not fulfill the educational requirement of progressively more difficult material from month to month. If the reading difficulty is beyond the present development of pupils to whon the selection is assigned, then they cannot be expected to read it at sight. Attemping sight reading orally with immature boys and girls usually brings difficulty either way it is looked at.

USE OF MATERIALS GREATLY BEYOND THE READING LEVEL

OF PUPILS

Good principles of teaching suggest that the menu provided for pupils should be neither too easy nor too difficult, but just a few degrees beyond the stage of development of the majority in the group. The assignment is then neither nauseating nor terrifying. Instead of beginning at the reading level already attained by pupils and gradually leading them on to more difficult selections, the teacher frequently accepts in detail the course of study as handed to him and proceeds to try to teach all of it. It is the tradition to teach Shakespeare and other English literature; therefore, these will be the selections studied. In many schools these beautiful, meaningful selections, as well as cqually excellent ones from American literature, are being read so ineffectively, both silently and orally, that the process resembles deciphering or the translation of a foreign language. Attempts at oral reading of difficult selections are often painful, inefficient, totally lacking in interest and thoroughly discouraging to a large majority of pupils.

At a time when secondary schools are enrolling pupils from every group in society it is difficult to understand why schools cling so tenaciously to the "classics" for all pupils. Modern authors and publishers have produced an abundance of excellent reading material bound in usable, inexpensive volumes which really attract rather than repel. When a pupil reads interesting selections in an attractively published book, and when he meets with a measure of success in his work, he is then "set" toward improvement. We ought always to try to help pupils experience greater pleasure day by day and a genuine internal satisfaction in all of their school work. The field of English specially affords the teacher an excellent opportunity to bring success and satisfaction to boys and girls.

\section{'TELLING PLPILS TO READ WITHOUT TEACHING THEM HOW TO READ}

Long hours of time are being given to reading in schools of all grades and levels, yet the quality of reading does not seem to improve very rapidly. Dr. McClusky and other educators familiar with the deplorable situation are begin- 
ning to "speak out" for a better quality of oral reading. I should like to speak out for a better quality of both oral and silent reading. And one of these days, if the situation is not remedied, schools will be hearing from parents who know full well that many secondary-school pupils just cannot read.

Oral reading is of great importance, and year by year it takes on greater importance as the use of the radio and intercommunicating systems in schools and places of business become more widespread. We must not, however, forget the ever increasing importance of silent reading. The power and ability to reud silently is the most important of all school achievements. Success in every other subject depends on the ability to read the printed page understandingly, quickly, and accurately. Only when the pupil develops this power and ability is he able to study history, mathematics, and science, and thus to help educate himself. The pupil who does not learn to read with understanding is to a great extent dependent on teachers and companions for his ideas, and on them for the interpretation of ideas.

Teachers in charge of supervised or directed study periods and study halls are constantly saying to pupils, "Study." "Now study your lessons," often without realizing that the special need of the moment and the most important single thing the teacher can do for his pupils is to teach them how to study. Instead of telling pupils when to multiply, divide, add, or substract in the socalled story problems in mathematics it would be vastly better to teach them how to read and understand the meaning of words used in the problems. Failures in mathematics are more often due to inability to read intelligently than to a lack of mathematical ability. Failures in history, science, and the languages as well as in English are due in a large percentage of instances directly to lack of ability to read the English language with understanding.

THE EFFECT ON PUPILS OF READING WITH ALL BOOKS OPEN

Among the numerous questions which continue to arise and bother me while observing and examining the extensive use of both oral and silent reading in secondary schools, and the writer desires to have it clearly understood that he is considering reading at the secondary-school level only, there are four which have been discussed with numerous teachers, and which still cause sleepless nights. These questions are: (1) What is the effect on a reader when he is conscious that his supposed listeners have before them the text material he is to read? (2) Would the person tend to improve his reading more rapidly if he were given opportunity to read without interruption and with special attention to thought? (3) What is the total effect on immature children when they are constantly taught to look for wrongs and errors in an activity rather than for right performance? (4) What attitude of attention brings the greatest amount of information to listeners? 


\section{Watching the Text vs. Listening to the Reading}

One might well inquire concerning the effect on the reader and on his skill in reading when the sensitive, teen-age pupil knows that text material is being watched by others. Pupils at that age find it difticult at best to be normal when performing before their friends and acquaintances, and it is doubly difficult when the performer realizes that he may be sharply criticized if he omits a comma or mispronounces a word. While one pupil is reading aloud in a secondary school no other pupil in the class or assembly should have an open book before him, and everyone in the audience should try to improve his ability to listen thoughtfully. There is great need in this country for the development of the ability to listen.

\section{Reading With Attention to Thought and Without Interruption}

When the intent really is to improve the quality of reading it would seem to this writer, even though he is merely a constant observer and not a professionally trained teacher in the field of reading, that the pupil should be asked to concentrate on the thought, that he should be expected to read in such a way as to give meanings, and that he should not be interrupted until he has finished even though some words are mispronounced. My experience with interpreters in foreign lands while trying to address audiences in a strange tongue is sufficiently vivid to convince me that either interpreters or interrupters are generally a nuisance.

\section{Training Pupils to Watch for Errors}

For more than thirty minutes one morning some months ago the writer listened to adverse criticisms of the reading performance of the previous day. He listened until he could stand it no longer. The pupils in that class were so trained to look for errors they could find flaws even in excellent reading.

After twenty minutes in another class I returned and found more of the same hunting for faults. What a mire of error and inaccuracy those pupils were plunged into as their introduction to school for that day! Not one word of approval and no indication that anything had been done in a satisfactory manner during the total class period of the previous day. Surely this is a wrong procedure. Such a teacher ought to study and try to observe some of the more common laws of learning.

\section{Attention to Mechanics vs. Attention to Thought}

The practice of having pupils read aloud round and round the class is very common in the smaller secondary schools throughout the country. Teachers inform me that pupils like to study (?) their lessons in this way. But, are they studying? Are they getting at meanings?

It seems to me that when oral reading is used to help pupils understand a selection, almost no attention should be called to punctuation marks. Pupils 
stould be instructed to try to get and give the meaning. The whole and undivided attention of the class should be on getting the thought. A pupil might at times say: "I wonder whether the author meant what Jack read. It seems to me that he meant ...," and here the pupil might read the same sentence to show what it means to him. The attention of all should be centered on getting at the meaning. With attention centered on mechanics many pupils ohtain very little of the meaning of the selection even after hearing it read aloud. The purpose of both teacher and pupils has been defeated, valuable time has been wasted, and wrong habits have been established.

\section{THE SUDDEN SHIFT OF PERFORMERS}

As one thinks of the practice of abruptly calling on a pupil to "take up from there," he begins to wonder whether it is possible under such circumstances for a pupil to develop the ability to read. Is it possible for the paipil tc get ready to convey the thought which is coming when he is aware that at almost any moment he may be called on to relinquish his place to another? Such a procedure may help to discipline the class, but it is not very useful for the purpose of teaching reading.

In one school recently visited the administrator agreed that they had changed from the forty-minute period to the hour period in order to have every pupil in class throughout the day for the sake of better discipline. On investigation it was found that even in classes a good deal of disturbance prevailed. The common practice was to have the lessons read in class from the texts. Whenever a pupil seemingly was not paying attention he was to be called on. 'This did hclp to control discipline but pupils certainly were not learning to read understandingly. It is not possible for a person to read effectively when he is permitted only to call words until the teacher says, "John, take up from there."

\section{SMALL AMOUNT OF TIME GIVEN TO EACH PUPIL}

A story current in World War $I$ is again going the rounds concerning the ability of soldiers to read. The private in question, somewhere in the Solomons, received a letter from home. Not being able to read, he called to a friend to ask if he could read "writin'." The reply came, "H-, no. I can't even read readin'. I went only to the eighth grade."

So little time is available in many schools for pupils to obtain practice in reading that it is little wonder many of them really never learn to read. This is tragic. Something ought to be done about it. Yet the teachers seem almost stymied with their large classes, with war rationing and with many other extra activities. Here is one suggestion which has been tried and has been actually found to work.

In a farm home years ago the mother, though not a teacher, discovered a way to get her children to learn to read. With proper encouragement and 
tıming, cach child took home a book and read to the mother. Since there was crily one copy of the book, it was important that the reader understand what he read and that he do his reading aloud skillfully. It is not recalled that the "ttacner", ever said that the reader forgot punctuation marks, but often she did say that she had not fully understood the meaning. Then the child tried specially hard to convey the meaning. Those boys and girls learned to read. Here is a suggestion worthy the consideration of the P.T.A. some evening when the widely advertised, often useless "outside speaker" fails to put in an appearance.

\section{SUMmary}

This writer believes that a thoughtful examination of the present-day reading situation as it exists among teen-age youth will show that the average reading ability of high-school pupils is at a disgraceful low level despite the diligent work of many classroom teachers and reading specialists. The following suggestions from a lay observer are offered as aids to the improvement of reading ability: (1) Teach pupils the meaning of the word "read" and hiclp them to understand meanings prior to the time they are called on to convey these meanings to others; (2) Encourage pupils to assume a larger individual and personal responsibility for the development of power to read understandingly; (3) Make a more extensive use of good quality materials in aitractively published modern texts; (4) Provide for much more free reading, both silent and oral, and delay the intensive study of the classics until pupils have a background for this kind of study; (5) Examine carefully reading practices now in use to see whether common laws of learning are being violated; (6) Plan for co-operation among all teachers for the improvenent of reading ability in every subject; and (7) Encourage parents to work with teachers in providing opportunities for pupils to obtain practice in both silent and oral reading.

\section{NEW RESOURCE UNITS}

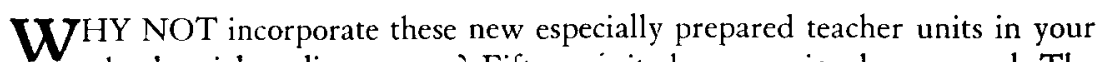
school social studies courses? Fifteen units have previously appeared. The following new ones are now available:

No. 16. America's Schools.

No. 17. Politics in Action.

No. 18. The IIealth of a Mation.

No. 19. The American Way of Business.

No. 20. The Americam Standard of Living.

No. 21. Urban and Rural Living.

Thirty cents per unit; discount for quantities.

ORDER FROM THE

National Association of Secondary-School Principals, 1201 Sixteenth Street, N. W., Washington 6, D. C. 